\title{
Intestinal and hepatic nitrogen balance in the rat after the administration of an oral protein load
}

\author{
BY JOSÉ ANTONIO FERNÁNDEZ-LÓPEZ, JAVIER CASADO, \\ MONTSERRAT ESTEVE, IMMACULADA RAFECAS, JOSEP MARIA ARGILÉS, \\ XAVIER REMESAR AND MARIÀ ALEMANY* \\ Departament de Bioquimica i Fisiologia, Universitat de Barcelona, 08028 Barcelona, Spain
}

(Received 27 July 1991-Accepted 4 June 1992)

\begin{abstract}
The fate of a small oral dose of protein given to overnight-starved rats was studied. After $3 \mathrm{~h}, 62 \%$ of the protein amino acids had been absorbed. Most of the absorbed $\mathrm{N}$ went into the bloodstream through the portal in the form of amino acids, but urea and ammonia were also present. About one-quarter of all absorbed $\mathbf{N}$ was carried as lymph amino acids. The liver was able to take all portal free ammonia and a large proportion of portal amino acids, releasing urea. The hepatic $\mathbf{N}$ balance was negative, indicating active proteolysis and net loss of liver protein.
\end{abstract}

Liver: Intestine: Protein load: $\mathbf{N}$ balance: Rat

After a meal the products of protein breakdown, essentially amino acids, are absorbed through the intestine (Wiseman, 1968), and sifted and partly retained by the liver (Ohnen et al. 1956; Schimassek \& Gerok, 1965; Demigné \& Rémésy, 1977). A proportion of the amino acids taken up is converted into other amino acids (Dent \& Schilling, 1949; Goldberg \& Guggenheim, 1962), part is used for an increased synthesis of protein (Omstedt $\&$ van der Decken, 1974) and the rest is deaminated and the hydrocarbon skeletons are used in the metabolism for energy (Krebs, 1969) or gluconeogenesis (Felig, 1973). The fine modulation of the fate outlined for ingested $\mathrm{N}$ is essentially dependent on the amino acid composition of the meal (Fafournoux et al. 1990) as well as on the actual immediate needs of the organism, for both energy and $\mathrm{N}$ (Young, 1987).

There has been much research on the actual role of splanchnic organs in the retention, transformation and eventual oxidation of the ingested amino acids (Ohnen et al. 1956; Schimassek \& Gerok, 1965; Marliss et al. 1971; Demigné \& Rémésy, 1977). However, the numerous methodological problems caused by the long digestion periods needed for protein breakdown and absorption (Darcy, 1984) have made it difficult to apply quantitative criteria when establishing the fate of ingested protein.

We present here the $\mathrm{N}$ balance of intestine and liver measured under controlled conditions for $3 \mathrm{~h}$ after the administration of a standard protein load.

\section{MATERIALS AND METHODS}

Male Wistar rats weighing $200-220 \mathrm{~g}$ were used. The animals were kept under standard conditions (temperature $22-23^{\circ}$; lights on from 08.00 to 20.00 hours; humidity $65-75 \%$ ) and were fed on type A02 chow pellets (Panlab, Barcelona, Spain) and tap water. The animals were kept without food for $24 \mathrm{~h}$ before the administration of the protein load

* For reprints. 
Table 1. Mean values of the metabolic variables measured in rats in 180 min period after receiving an oral load of protein

(Values are means of groups of five to six animals used for each measurement)

\begin{tabular}{|c|c|c|c|c|c|c|}
\hline \multirow[b]{2}{*}{ Variable } & \multirow[b]{2}{*}{ Site } & \multicolumn{2}{|c|}{ Range* } & \multirow[b]{2}{*}{ Mean $\dagger$} & \multicolumn{2}{|c|}{$\begin{array}{c}\text { Statistical } \\
\text { significance } \\
\text { of effect of time } \\
\text { (one-way ANOVA) } \ddagger\end{array}$} \\
\hline & & Minimum & Maximum & & $F$ & $P$ \\
\hline \multirow{4}{*}{$\alpha-\mathrm{NH}_{2}-\mathrm{N}(\mathrm{mm})$} & PV & $5 \cdot 0^{120} \S$ & $6 \cdot 9^{150}$ & 62 & $2 \cdot 67$ & 0.03 \\
\hline & $\mathrm{SHV}$ & $4 \cdot 8^{90}$ & $6 \cdot 8^{0}$ & $6 \cdot 1$ & 2.99 & 0.02 \\
\hline & AA & $4 \cdot 4^{90}$ & $7 \cdot 5^{\circ}$ & 6.0 & $2 \cdot 21$ & 0.07 \\
\hline & lymph & $5 \cdot 6^{180}$ & $7 \cdot 0^{90}$ & 63 & 0.58 & 0.74 \\
\hline \multirow{3}{*}{ Urea (mM) } & PV & $5 \cdot 7^{30,120}$ & $8 \cdot 1^{60}$ & $6 \cdot 6$ & $9 \cdot 24$ & 0.00 \\
\hline & SHV & $6 \cdot 0^{\circ}$ & $7 \cdot 9^{90}$ & 68 & $4 \cdot 39$ & 0.00 \\
\hline & $\mathrm{AA}$ & $5 \cdot 8^{120}$ & $7 \cdot 7^{60}$ & $6 \cdot 6$ & 301 & 0.02 \\
\hline \multirow[t]{3}{*}{ Ammonia $(\mu \mathrm{M})$} & PV & $84^{60}$ & $141^{150}$ & 112 & 0.96 & 0.51 \\
\hline & SHV & $13^{120}$ & $49^{30}$ & 26 & $2 \cdot 76$ & 0.03 \\
\hline & $\mathrm{AA}$ & $13^{120}$ & $34^{180}$ & 23 & $1 \cdot 24$ & $0 \cdot 32$ \\
\hline \multirow[t]{3}{*}{ Glucose (mM) } & PV & $4 \cdot 5^{0.30}$ & $5 \cdot 5^{180}$ & $5 \cdot 0$ & $1 \cdot 21$ & $0 \cdot 33$ \\
\hline & SHV & $4.9^{0}$ & $5 \cdot 6^{180}$ & $5 \cdot 2$ & 0.45 & 0.84 \\
\hline & $\mathrm{AA}$ & $4 \cdot 9^{0}$ & $5 \cdot 9^{1.50}$ & $5 \cdot 3$ & 1.76 & $0 \cdot 14$ \\
\hline \multirow[t]{3}{*}{ Lactate (mm) } & PV & $1.00^{90}$ & $1 \cdot 55^{\circ}$ & 1.27 & $2 \cdot 29$ & 0.06 \\
\hline & SHV & $0 \cdot 68^{90}$ & $1.08^{0}$ & 0.89 & 1.91 & 0.12 \\
\hline & $\mathrm{AA}$ & $0.72^{60}$ & $1.25^{\circ}$ & 0.99 & 1.52 & 0.21 \\
\hline Glycogen $(\mu \mathrm{mol})$ & liver & $60^{30}$ & $87^{180}$ & 74 & 0.67 & $0 \cdot 67$ \\
\hline \multirow[t]{2}{*}{ Plasma IR insulin (mU/1) } & PV & $28^{180}$ & $83^{60}$ & 52 & $17 \cdot 62$ & 0.00 \\
\hline & $\mathrm{AA}$ & $7 \cdot 5^{120}$ & $19 \cdot 6^{60}$ & $9 \cdot 4$ & $4 \cdot 01$ & 0.01 \\
\hline \multirow[t]{3}{*}{ Blood flow $(\mu 1 / s)$} & PV & $152^{60}$ & $275^{120}$ & 208 & $2 \cdot 42$ & 0.05 \\
\hline & SHV & $267^{60}$ & $582^{120}$ & 370 & $11 \cdot 43$ & 0.00 \\
\hline & $\mathrm{HA}$ & $77^{150}$ & $313^{120}$ & 162 & - & - \\
\hline
\end{tabular}

PV, portal vein; SHV, suprahepatic vein; HA, hepatic artery; AA, aorta.

* Maximum and minimum values (for time-group means) found in the 180 min studied after oral load.

$\dagger$ Mean for the 180 min time interval.

$\ddagger 27-29 \mathrm{df}$.

$\$$ Superscript numbers represent the time-interval after load (at $30 \mathrm{~min}$ intervals) when these maximum and minimum values were attained.

(between 10.00 and 12.00 hours). The protein load was given by means of a stomach cannula, and contained $300 \mathrm{mg}$ protein (a widely used dietary protein supplement, Top Protein 90; Eurodietética, Madrid, Spain) of known amino acid composition (equivalent to $2.04 \mathrm{mmol}$ amino acids; the mixture represented a mean 1.298 atoms $\mathrm{N}$ per amino acid molecule), suspended in $2 \mathrm{ml}$ water. The rats were killed at $30 \mathrm{~min}$ intervals after the administration of the protein, up to $180 \mathrm{~min}$. At $5 \mathrm{~min}$ before killing the rats were anaesthetized with an intraperitoneal injection of sodium pentobarbital $(60 \mathrm{mg} / \mathrm{kg})$. At the stated times samples of portal and aortic blood were obtained with heparinized $1 \mathrm{ml}$ syringes. Portions of blood were immediately centrifuged and their plasma used for the estimation of ammonia (DaFonseca-Wollheim, 1973a,b). The remainder was stored at $-30^{\circ}$ until processing for analyses.

Blood samples were deproteinized with acetone and $\alpha-\mathrm{NH}_{2}-\mathrm{N}$ was measured using a fluorescamine method (Klein \& Standaert, 1976). Glucose (Trinder, 1969), lactate (Gutmann \& Wahlefeld, 1974) and urea (Fawcett \& Scott, 1960) were measured by enzymic methods in blood deproteinized with perchloric acid (removed with $\mathrm{K}_{2} \mathrm{CO}_{3}$ ). Immunoreactive insulin was measured in plasma with a radioimmunoassay method using rat 


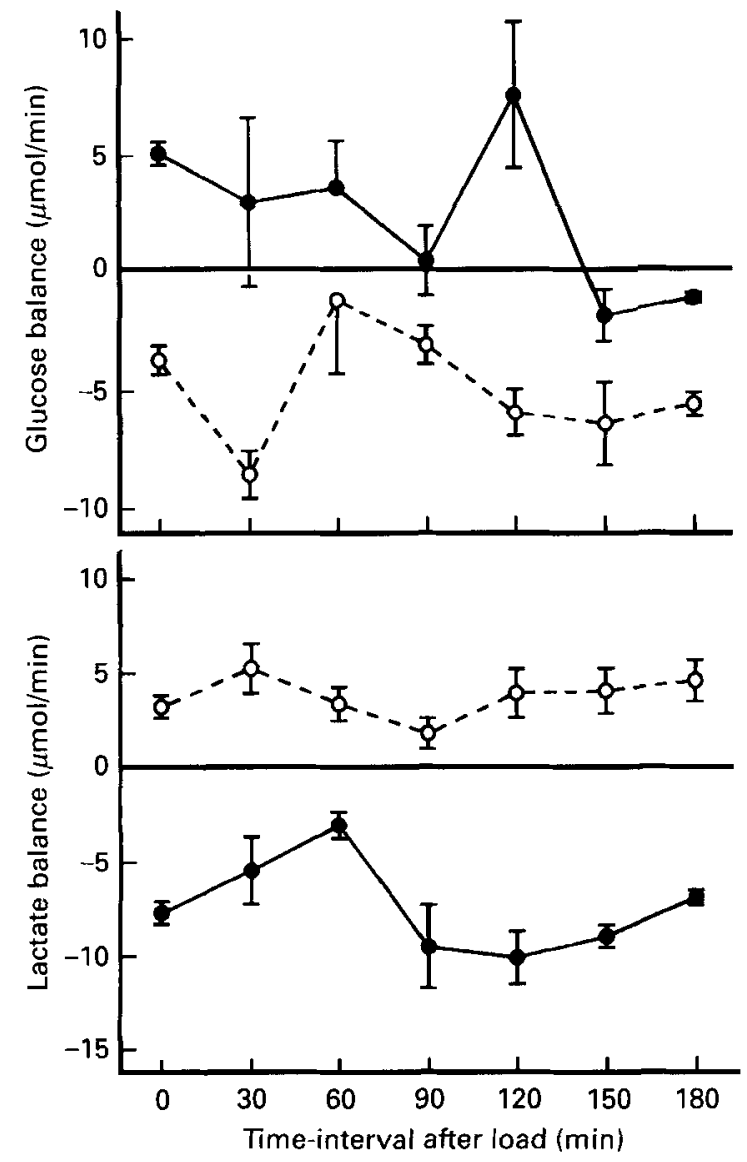

Fig. 1. Intestinal (O-- $\mathrm{O})$ and hepatic (O-O) glucose and lactate balances in rats for $3 \mathrm{~h}$ after the administration of an oral load of protein. The points represent the means with their standard errors for five to six animals. Positive balance (for both liver and intestine) represents a net release, and a negative balance represents a net uptake. Statistical analysis (ANOVA) of the effect of time-interval after load

\begin{tabular}{lccc} 
Variable & df & $F$ & $P$ \\
\hline $\begin{array}{l}\text { Glucose balance: } \\
\quad \text { Intestinal }\end{array}$ & 6,27 & 2.61 & 0.0398 \\
$\quad$ Hepatic & 6,27 & 1.93 & 0.1115 \\
$\begin{array}{l}\text { Lactate balance: } \\
\quad \text { Intestinal }\end{array}$ & 6,27 & 0.62 & 0.7117 \\
$\quad$ Hepatic & 6,27 & 1.11 & 0.3800
\end{tabular}

insulin as standard (Heding, 1972; Iglesias et al. 1985). Liver glycogen was estimated after alkaline digestion (Good et al. 1933).

Another series of rats was treated as described previously, but a mesenteric vein was cannulated and infused with $p$-aminohippurate. The dilution pattern of the marker was then used for the estimation of portal and suprahepatic vein as well hepatic artery blood flow (Katz \& Bergman, 1969; Casado et al. 1987).

A third series of rats was used for the extraction (under sodium pentobarbital anaesthesia) of intestinal lymph samples at the stated times after oral dosing, using plastic syringes and fine gauge hypodermic needles. These lymph samples were used for the 

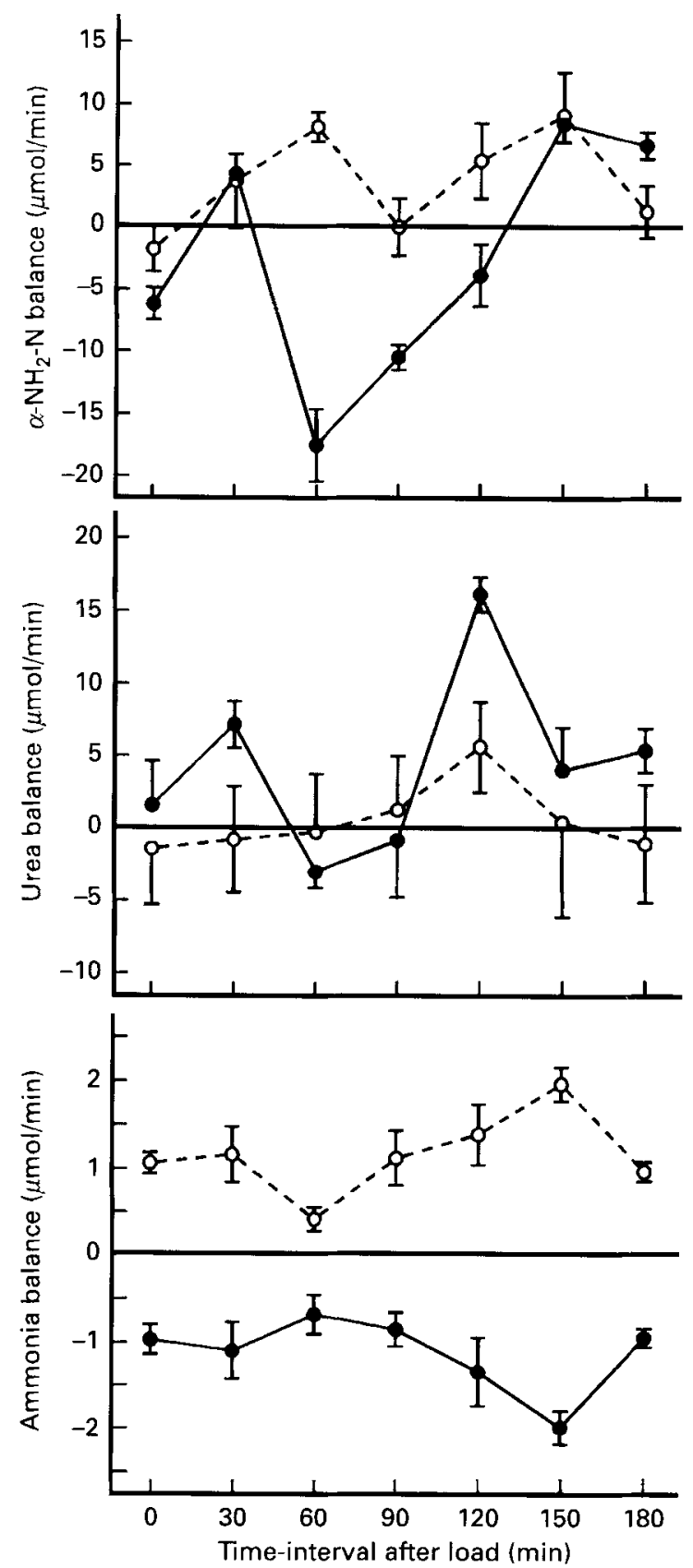

Fig. 2. Intestinal $(\mathrm{O}-\mathrm{O})$ and hepatic $(-\mathrm{-}) \alpha-\mathrm{NH}_{2}-\mathrm{N}$, urea and ammonia balances in rats for $3 \mathrm{~h}$ after the administration of an oral load of protein. The points represent the means with their standard errors for five to six animals. Positive balance (for both liver and intestine) represents a net release, and a negative balance represents a net uptake. Statistical analysis (ANOVA) of the effect of time-interval after load

\begin{tabular}{lccc} 
Variable & df & $F$ & $P$ \\
\cline { 1 - 1 }$\alpha-\mathrm{NH}_{2} \mathrm{~N}$ balance: & & & \\
$\quad$ Intestinal & 6,28 & $2 \cdot 75$ & $0 \cdot 0316$ \\
Hepatic & 6,28 & 8.30 & $0 \cdot 0000$
\end{tabular}


estimation of total $\alpha-\mathrm{NH}_{2}-\mathrm{N}$ with fluorescamine (Klein \& Standaert, 1976) only, because of their small volume.

The portal and arterial concentrations and blood flows were used to calculate net intestinal amino acid, urea, and ammonia balances (IB) across the intestine, by using the formula:

$$
\mathrm{IB}=\Phi_{\mathrm{P}}\left[\mathrm{C}_{\mathrm{P}}-\mathrm{C}_{\mathrm{A}}\right]
$$

where $\Phi_{\mathrm{P}}$ is the portal blood flow at a given time; $\mathrm{C}_{\mathrm{P}}$ and $\mathrm{C}_{\mathrm{A}}$ are the concentrations at a given time in portal and arterial blood respectively. Likewise, for hepatic balances:

$$
\mathrm{HB}=\Phi_{\mathrm{H}} \mathrm{C}_{\mathrm{H}}-\left[\Phi_{\mathrm{P}} \mathrm{C}_{\mathrm{P}}-\Phi_{\mathrm{A}} \mathrm{C}_{\mathrm{A}}\right]
$$

where $\mathrm{C}_{\mathrm{H}}$ is the suprahepatic vein concentration, and $\Phi_{\mathrm{H}}$ and $\Phi_{\mathrm{A}}$ are the suprahepatic vein and hepatic artery blood flows respectively.

The combined portal (small and large intestine, spleen, stomach, etc.) blood flow of conscious (fed and $24 \mathrm{~h}$ starved) rats was measured with a radioactive microsphere distribution method (Ahokas et al. 1984), and compared with the values obtained in rats anaesthetized ( 5 min earlier), using the $p$-aminohippuric acid dilution method.

Statistical significance of the differences between means was established with a standard one-way analysis of variance program, with the limit of significance set at $P<0.05$.

\section{RESULTS}

The amount of label derived from the oral protein load and present in the intestine and its contents diminished progressively with time. At $180 \mathrm{~min}$, a mean $38 \%$ of the label remained in the intestine, the rest was to be found in other body compartments or was lost as excretion products. This $62 \%$ of the protein was considered the amount of $\alpha-\mathrm{NH}_{2}-\mathrm{N}$ actually taken up by the intestine and released into the bloodstream.

The portal blood flow of conscious fed rats estimated with a radioactive microspheres method was 315 (SEM 42) $\mu \mathrm{l} / \mathrm{s}$, and that obtained with the $p$-aminohippuric acid dilution method 297 (SEM 17) $\mu \mathrm{l} / \mathrm{s}$; for $24 \mathrm{~h}$ starved rats, the results were respectively 169 (SEM 32) $\mu \mathrm{l} / \mathrm{s}$ and 183 (SEM 26) $\mu \mathrm{l} / \mathrm{s}$ ( $n 5$ for all four groups). No significant differences in the results were observed attributable to the method of measurement of blood flow. Both methods showed significantly lower $(P<0.05)$ values for starved $v$. fed values.

Table 1 shows the means of the metabolic variables measured in rats that received an oral load of protein. The circulating levels of $\alpha-\mathrm{NH}_{2}-\mathrm{N}$, urea, ammonia, glucose and lactate showed little variation during the $180 \mathrm{~min}$ study. No changes were appreciated either in liver glycogen content. Plasma insulin practically halved after the first hour. The widest variation was observed in portal blood flow (by almost a factor of six).

From the data summarized in Table 1, the hepatic and intestinal balances for glucose and lactate are presented in Fig. 1, and those for $\alpha-\mathrm{NH}_{2}-\mathrm{N}$, urea and ammonia are shown in Fig. 2. The intestine showed a constant uptake of glucose from the bloodstream and a continued output of lactate, whereas the liver took up more lactate than that produced by the intestine and released limited amounts of glucose during the first hour and $2 \mathrm{~h}$ after the oral load.

The intestine showed a continued net positive balance of $\alpha-\mathrm{NH}_{2}-\mathrm{N}$ for the $3 \mathrm{~h}$ studied.

$\begin{array}{llll}\text { Urea balance: } & & & \\ \quad \text { Intestinal } & 6,28 & 0.35 & 0.9055 \\ \quad \text { Hepatic } & 6,28 & 6.04 & 0.0004 \\ \text { Ammonia balance: } & & & \\ \quad \text { Intestinal } & 6,28 & 6.20 & 0.0006 \\ \quad \text { Hepatic } & 6,28 & 4.63 & 0.0022\end{array}$


The liver changed from a net initial negative balance to a transient net release at $30 \mathrm{~min}$ followed by a longer period of net accumulation of amino acids. The last part of the period studied again showed a net positive balance for liver amino acids.

There was a small production of urea by the intestine, peaking at $120 \mathrm{~min}$. The liver produced larger amounts of urea at $30 \mathrm{~min}$ and again from $120 \mathrm{~min}$ onwards; the maximum rate of production was attained at $120 \mathrm{~min}$. The pattern of release of ammonia from the intestine changed little with time, showing a minimum at $60 \mathrm{~min}$ and a maximum at $150 \mathrm{~min}$. The net liver uptake of ammonia was practically a mirror image of this pattern (Fig. 2).

A very high proportion of the digestion of the protein load was completed within $3 \mathrm{~h}$, since about two-thirds were already absorbed as amino acids (i.e. more than $90 \%$ of the peptide bonds must have been split for such an amount of amino acids to be released). Coinciding with the absorption, several changes took place in a short time; the intestinal glucose consumption increased, probably a reflection of the higher energy needed to process the protein load. The intestinal release of amino acids peaked in about $60 \mathrm{~min}$, coinciding with the highest hepatic uptake and lowest glucose consumption and lactate and ammonia production by the intestine. This coincided also with the lowest hepatic glucose output, maintaining the glycaemia, however, and lactate uptake. After that phase the liver and intestine increased their amino acid efflux; urea production was significant for both liver and intestine and liver glucose output and ammonia intake also increased. At $180 \mathrm{~min}$, most variables tended to return to the pre-load levels, except for hepatic glucose and amino acid balances.

\section{DISCUSSION}

Anaesthesia is known to affect organ blood flow and glycaemia in the rat (Arola et al. 1981; Lang et al. 1986; Tuma et al. 1986; Pénicaud et al. 1987). The strategy used here, of minimizing the effects of anaesthesia by limiting its duration, has little effect on blood flows, since the data obtained on conscious animals with a suitable radioactive microsphere method gave values very close to those obtained with the $p$-aminohippuric acid dilution method under the limited-anaesthesia conditions outlined. Since the portal data flows for conscious animals were also in the range of values in the literature obtained under similar conditions in fed rats (Ishishe et al. 1980), it can safely be assumed that the effects of our anaesthesia protocol on the blood flows of rats receiving the oral protein load are minimal.

Food deprivation in the rat for $24 \mathrm{~h}$ affects its levels of reserves, especially glycogen (Newgard et al. 1983; Katz et al. 1986); the levels observed were very low, in agreement with those expected after overnight fasting (Palou et al. 1981). Glycaemia, however, was well maintained, in part because of liver gluconeogenesis from lactate and amino acids (Felig et al. 1970; Exton, 1972); the liver showed an initial (time 0) net, albeit small, glucose production. The uptake of lactate and $\alpha-\mathrm{NH}_{2}-\mathrm{N}$ and net urea release agree with this interpretation. The administration of a relatively small oral protein load (about $5 \mathrm{~kJ}$ of energy) had little effect. Since a rat that size has a mean energy output of about $2 \mathrm{~W}$ (Rafecas et al. 1989), the energy of the whole load was in a range of about one-quarter of that actually required for maintenance during the $3 \mathrm{~h}$ span studied.

Intestinal lactate production was in part a consequence of high intestinal glucose consumption (Nicholls et al. 1983), but the lactate produced was less than one-third of the glucose consumed by the intestine.

The contribution of lymph to the transport of amino acids from the intestinal lumen to the bloodstream is only an estimate, based on indirect lymph flow measurements (Fernández-López et al. 1992), but it represents a substantial proportion (about onequarter of all absorbed $N$ ) with respect to the net amino acid efflux through the portal. The 


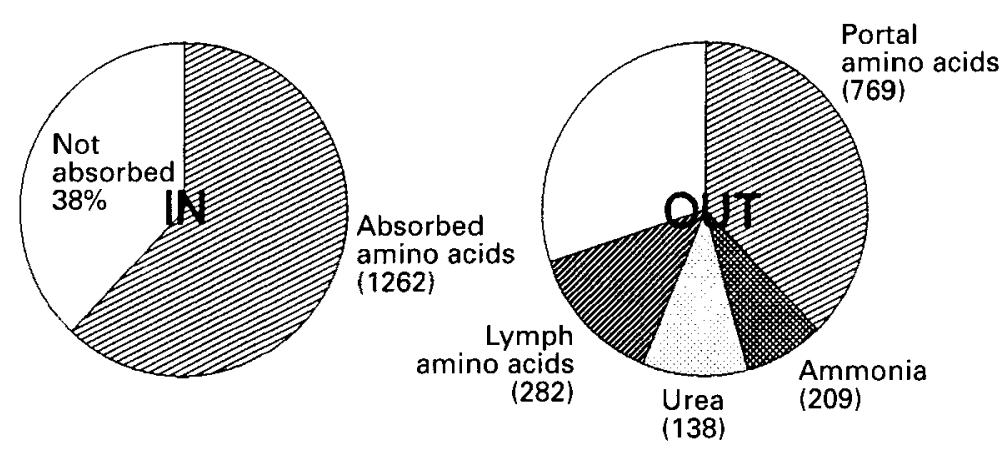

Hepatic $\mathrm{N}$ balance
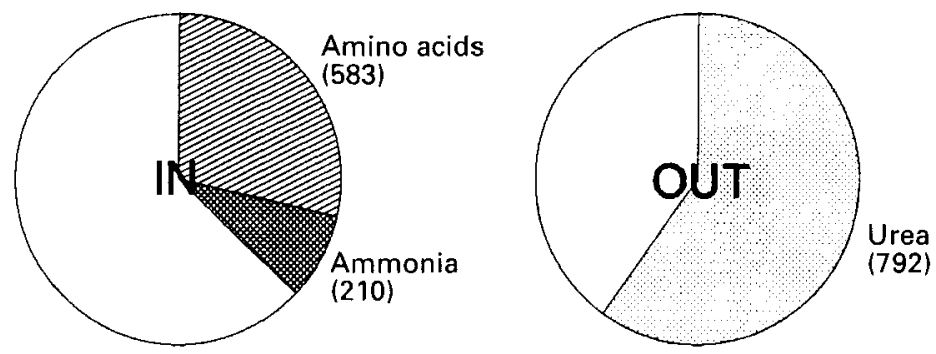

Fig. 3. Cumulative $3 \mathrm{~h}$ intestinal and hepatic $\mathrm{N}$ balance in rats after an oral load of protein. Values in parentheses represent $\mathrm{N}$ in each component $(\mu \mathrm{mol})$. Since there are no values available for the actual composition of lymph and portal amino acid balances, the value has been obtained by applying the same value for $\mathrm{N}$ atoms/amino acid molecule as that in the initial protein load.

intestine profoundly alters the amino acid composition of the load in coordination with the uptake abilities of liver and other organs (Demigné \& Rémésy, 1977). Lymph amino acids would circumvent the splanchnic bed organs and thus, would be directly available to peripheral organs.

Fig. 3 shows a synopsis of the fate of the protein load in $180 \mathrm{~min}$, presented as $\mathrm{N}$ balances of intestine and liver. The intestinal $\mathrm{N}$ balance after $3 \mathrm{~h}$ was practically zero, with most of the output in the form of $\alpha-\mathrm{NH}_{2}-\mathrm{N}$, in agreement with data in the literature (Goldberg \& Guggenheim, 1962; Demigné \& Rémésy, 1977; Fafournoux et al. 1990). A small but significant part of the overall $\mathrm{N}$ balance was due to a net intestinal urea balance, probably as a consequence of its arginase activity (Konarska \& Tomaszewski, 1975), and a similar proportion of ammonia (Van Leeuwen et al. 1984; Weber et al. 1988). Lymph flow contributed a sizeable proportion of intestinal amino acid output. The results presented suggest that intestinal urea production, under the conditions studied, can over-compensate its known hydrolysis by the flora (Gibson et al. 1976). The net synthesis observed is very probably limited in time to conditions of high energy demand and high luminal amino acid availability.

The intestine produces ammonia mainly as a result of glutamine deamidation (Weber et al. 1988; Hartmann \& Plauth, 1989), a process acting essentially on systemic glutamine synthesized in peripheral organs. The liver is able to retain practically all portal ammonia 
(Rémésy et al. 1986; Cooper et al. 1987), i.e. it recovers all the ammonia released by the intestine. The fate of this ammonia is split between glutamine production and, especially, urea synthesis (Häussinger, 1987, 1989). The large liver urea output cannot be explained only as a need to detoxify portal ammonia, since this can only justify about one-third of that needed for the synthesis of the urea released by the liver. Consequently, under the conditions stated, the liver had a high ammoniogenic potential from amino acids (Shepartz, 1973). This is in agreement with its gluconeogenic role during food deprivation (Felig et al. 1970; Aikawa et al. 1973) and its ability to sustain its metabolism with amino-acid-derived energy.

The net hepatic $\mathrm{N}$ balance in $3 \mathrm{~h}$ was clearly negative, since the urea output was much larger than the combined influx of ammonia and amino acids. The balance could only come from liver protein made available as an energy source through proteolysis (Mortimore $\&$ Pösö, 1984). The balance depicted in Fig. 3 could be justified with about $4 \%$ of liver protein, a value not far from the changes in protein content the liver undergoes during starvation (Mortimore \& Pösö, 1984).

The results presented suggest an efficient and very active disposal of an oral load of amino acid-N by the intestine and liver which, thus, seem to make their energy-rich hydrocarbon skeletons available for metabolic maintenance.

This work was supported by a grant, PB86-512, from the Dirección General de Investigación Científica y Técnica from the Government of Spain. Thanks are given to Robin Rycroft for his help in editing the manuscript.

\section{REFERENCES}

Ahokas, R. A., Reynolds, S. L., Anderson, G. D. \& Lipshitz, J. (1984). Maternal organ distribution of cardiac output in the diet-restricted pregnant rat. Journal of Nutrition 114, 2262-2268.

Aikawa, T., Matsutaka, H., Yamamoto, M., Okuda, T., Ishikawa, E., Kawano, T. \& Matsumura, E. (1973). Gluconeogenesis and amino acid metabolism. Il. Inter-organal relations and roles of glutamine and alanine in the amino acid metabolism of fasted rats. Journal of Biochemistry (Tokyo) 74, 1003-1017.

Arola, L., Palou, A., Remesar, X., Herrera, E. \& Alemany, M. (1981). Effect of ether, sodium pentobarbital and chloral hydrate anesthesia on rat plasma metabolite concentrations. Revista Española de Fisiologia 37, 379-386.

Casado, J., Pastor-Anglada, M. \& Remesar, X. (1987). Hepatic uptake of amino acids at mid-lactation in the rat. Biochemical Journal 245, 297-300.

Cooper, A. J. L., Nieves, E., Coleman, A. E., File-DeRicco, S. \& Gelbard, A. S. (1987). Short-term metabolic fate of $\left[{ }^{13} \mathrm{~N}\right]$-ammonia in rat liver in vivo. Joumal of Biological Chemistry 262, 1073-1080.

DaFonseca-Wollheim, V.F. (1973a). Bedeutung von Wasserstoffionenkonzentration und ADP-zusatz bei der Ammoniakbestimmung mit Glutamatdehydrogenase (The significance of the hydrogen ion concentration and the addition of ADP in the determination of ammonia with glutamate dehydrogenase). Zeitschrift für Klinische Chemie und Klinische Biochemie 11, 421-425.

DaFonseca-Wollheim, V.F. (1973b). Direkte Plasmaammoniakbestimmung ohne Enteiweissung (Direct determination of plasma ammonia without deproteinization). Zeitschrift für Klinische Chemie und Klinische Biochemie 11, 425-427.

Darcy, B. (1984). Availability of amino acids in monogastric animals. Diabète et Métabolisme 10, 121-133.

Demigné, C. \& Rémésy, A. C. (1977). Étude in vivo chez le rat nourri du métabolisme intestinal et hépatique des acides aminés (Study in vivo of hepatic amino acid metabolism in fed rats). Annales de Biologie, Biochimie et Biophysique 17, 615-620.

Dent, C. E. \& Schilling, J. A. (1949). Studies on the absorption of proteins: the amino-acid pattern in the portal blood. Biochemical Journal 44, 318-335.

Exton, J. M. (1972). Gluconeogenesis. Metabolism 21, 945-990.

Fafournoux, P., Rémésy, C. \& Demigné, C. (1990). Fluxes and membrane transport of amino acids in rat liver under different protein diets. American Journal of Physiology 259, E614-E625.

Fawcett, J. K. \& Scott, J. E. (1960). A rapid method for the determination of urea. Journal of Clinical Pathology $13,156-163$.

Felig, P., Pozefsky, T., Marliss, E. \& Cahill, G. F. (1970). Alanine: key role in gluconeogenesis. Science 167, $1003-1004$.

Felig, P. (1973). The glucose-alanine cycle. Metabolism 21, 197-207. 
Fernández-López, J. A., Casado, J., Argilés, J. M. \& Alemany, M. (1992). In the rat, intestinal lymph carries a significant amount of ingested glucose into the bloodstream. Archives Internationales de Physiologie, de Biochimie et de Biophysique 100, 231-236.

Gibson, J. A., Park, N. J., Sladen, G. E. \& Dawson, A. M. (1976). The role of colon in urea metabolism in man. Clinical Science and Molecular Medicine 50, 51-59.

Goldberg, A.\& Guggenheim, K. (1962). The digestive release of amino acids and their concentrations in the portal plasma of rats after protein feeding. Biochemical Journal 83, 129-135.

Good, C. A., Kramer, M. \& Somogyi, M. (1933). The determination of glycogen. Joumal of Biological Chemistry $100,485-494$

Gutmann, I. \& Wahlefeld, A. W. (1974). L-lactate. In: Methods of Enzymatic Analysis, pp. 1464-1468, vol. 4 [H. U. Bergmeyer, editor]. New York: Academic Press.

Hartmann, F. \& Plauth, M. (1989). Intestinal glutamine metabolism. Metabolism 38, 18-24.

Häussinger, D. (1987). Structural-functional organization of hepatic glutamine and ammonium metabolism. Biochemical Society Transactions 15, 369-372.

Häussinger, D. (1989). Glutamine metabolism in the liver: overview and current concepts. Metabolism 38, $14-17$.

Heding, L. G. (1972). Determination of total serum insulin (IRI) in insulin treated diabetic patients. Diabetologia 8, $260-266$.

Iglesias, R., Villarroya, F. \& Alemany, M. (1985). Comparison of the effects of different anticoagulants and sample handling procedures on rat insulin radioimmunoassay. Comparative Biochemistry and Physiology $\mathbf{8 2 A}$, 863-866.

Ishishe, S., Pegram, B. L., Yamamoto, J., Kitamura, Y. \& Frohlich, E. D. (1980). Reference sample microsphere method: cardiac output and blood flows in conscious rats. American Journal of Physiology 239, $\mathrm{H} 433-\mathrm{H} 449$.

Katz, J., Kuwajima, M., Foster, D. W. \& McGarry, J. D. (1986). The glucose paradox: new perspectives on hepatic carbohydrate metabolism. Trends in Biochemical Sciences 11, 136-140.

Katz, M. L. \& Bergman, E. N. (1969). Simultaneous measurement of hepatic and portal venous flow in the sheep and dog. American Joumal of Physiology 216, 946-952.

Klein, B. \& Standaert, F. (1976). Fluorometry of plasma amino nitrogen with the use of fluorescamine. Clinical Chemistry 22, 413-416.

Konarska, L. \& Tomaszewski, L. (1975). Studies on L-arginase of the small intestine. II. Intestinal arginase in young and adult mammals and its role in maintaining urea body pool. Biochemical Medicine 14, 263-273.

Krebs, H. A. (1969). The metabolic fate of amino acids. In: Mammalian Protein Metabolism, pp. 125-176, vol. 3 [H. N. Munro, editor]. New York: Academic Press.

Lang, C. H., Bagby, G. J., Brakerley, H. L., Johnson, J. L. \& Spitzer, J. J. (1986). Plasma glucose concentration determines direct versus indirect liver glycogen synthesis. American Journal of Physiology 251, E584-E590.

Marliss, E. B., Aoki, T. T., Pozefsky, T., Most, A. S. \& Cahill, G. F. (1971). Muscle and splanchnic glutamine and glutamate metabolism in postabsorptive and starved man. Journal of Clinical Investigation 50, 814 817.

Mortimore, G. E. \& Pösö, A. R. (1984). Lysosomal pathways in hepatic protein degradation: regulation role of amino acids. Federation Proceedings 43, 1289-1294.

Newgard, C. B., Hirsch, L. J., Foster, D. W. \& McGarry, J. D. (1983). Studies on the mechanism by which exogenous glucose is converted into liver glycogen in the rat. Journal of Biological Chemistry 258, 8046 8052.

Nicholls, T. J., Leese, H. J. \& Bronk, J. R. (1983). Transport and metabolism of glucose by rat small intestine. Biochemical Journal 212, 183-187.

Ohnen, K. H., Wade, O. L. \& Blainey, J. D. (1956). Amino acids in hepatic venous and arterial blood. Lancet ii, 1075-1076.

Omstedt, P. T. \& von der Decken, A. (1974). Dietary amino acids: effects of depletion and recovery on protein synthesis in vitro in rat skeletal muscle and liver. British Journal of Nutrition 31, 67-76.

Palou, A., Remesar, X., Arola, L1. \& Alemany, M. (1981). Metabolic effects of short term food deprivation in the rat. Hormone and Metabolic Research 13, 326-330.

Pénicaud, L., Ferré, P., Kande, J., LeTurque, A., Issad, T. \& Girard, J. (1987). Effect of anesthesia on glucose production and utilization in rats. American Journal of Physiology 252, E365-E369.

Rafecas, I., Domènech, T., Esteve, M., Remesar, X., Argilés, J. M. \& Alemany, M. (1989). The thermogenic effect of a sucrose gavage on the fa/fa rat. Nutrition Research 9, 1407-1413.

Rémésy, C., Demigné, C. \& Fafournoux, P. (1986). Control of ammonia distribution ratio across the liver cell membrane and ureogenesis by intracellular pH. European Journal of Biochemistry 158, 283-288.

Schimassek, B. \& Gerok, W. (1965). Control of the levels of free amino acids in plasma by the liver. Biochemische Zeitschrift 343, 407-415.

Shepartz, B. (1973). Overall amino acid metabolism. In: Regulation of Amino Acid Metabolism in Mammals, pp. 19-32. Philadelphia: W. B. Saunders.

Trinder, P. (1969). Determination of glucose in blood using glucose oxidase with an alternative oxygen acceptor. Annals of Clinical Biochemistry 6, 24-27.

Tuma, R. F., Vasthare, U. S., Irion, G. L. \& Wiedeman, M. P. (1986). Considerations in use of microspheres for flow measurements in anaesthetized rats. American Journal of Physiology 250, $\mathrm{H} 137-\mathrm{H} 143$.

Van Leeuwen, P. A. H., Bogaard, E. J. M., Janssen, M. A., deBoer, J. E. G., Eyck, H. M. A. \& Soeters, P. B. (1984). Ammonia production and glutamine metabolism in the small and large intestine of the rat and the 
influence of lactulose and neomycin. In: Advances in Hepatic Encephalopathy and Urea Cycle Diseases, pp. 164-172 [G. Kleinberger, P. Ferenci, P. Riederer and H. Thaler, editors]. Basel; Karger.

Weber, F. L., Friedman, D. W. \& Fresard, K. M. (1988). Ammonia production from intraluminal amino acids in canine jejunum. American Journal of Physiology 254, G264-G268.

Wiseman, G. (1968). Absorption of amino acids. In: Handbook of Physiology, pp. 1277-1307, vol. 3. Washington, DC: American Physiological Society.

Young, V. R. (1987). McCollum Award Lecture. Kinetics of human amino acid metabolism: nutritional implications and some lessons. American Journal of Clinical Nutrition 46, 709-725. 